\title{
VINCULAÇÃO E DISCRICIONARIEDADE ADMINISTRATIVA
}

\section{I}

O princípio da legalidade domina a ordem jurídica como fundamento de garantia de direitos políticos e individuais, opondo-se ao absolutismo do poder.

As Constituições brasileiras colocam historicamente entre os pressupostos essenciais a noção de que a lei é a medida necessária de deveres, direitos e obrigações, tanto nas relações privadas como no plano da atividade pública.

A Administração Pública, dotada de uma margem relativa de discricionariedade, em benefício do interesse geral, encontra na regra de competência, que qualifica o exercício da autoridade, a latitude do poder de agir. Dissemos, em outra oportunidade, que não é competente quem quer, mas quem pode, segundo a norma de direito.

Acompanhando o modelo contemporâneo das Constituições de Portugal e de Espanha - que como a nossa de 1988 sucederam a um regime autoritário - , a atual Constituição brasileira é pródiga em proclamar direitos e prerrogativas não somente em nível individual, como no plano social, inclusive no âmbito de direitos difusos e coletivos. O cidadão é, a par do indivíduo, a personagem da proteção constitucional.

A afirmação de demandas sociais e coletivas reclama da Administração Pública maior soma de iniciativas, alargando a área de prestação dos serviços públicos.

Diante da expectativa de conflitos potenciais entre os deveres do Estado e os direitos e liberdades, a Constituição de 1988 se esmera em explicitar os princípios fundamentais que condicionam a atuação administrativa.

Destaca o art. 37 que a Administração Pública, em todos os seus níveis, deve obediência aos princípios da legalidade, impessoalidade, moralidade e publicidade e, no art. 70, prescreve, entre os objetivos do controle financeiro, a legalidade, legitimidade e economicidade dos gastos públicos. Cumpre ao sistema de controle interno, entre outras finalidades, a de comprovar a legalidade e avaliar a eficácia e eficiência dos resultados da gestão administrativa (art. 74).

As decisões administrativas dos tribunais serão sempre motivadas, como impõe o item $\mathrm{X}$ do art. 93, e a ordem econômica, fundada na valorização do trabalho humano 
e na livre iniciativa, tem como parâmetro os ditames da justiça social, nos termos do art. 170 da Carta Magna.

Os quatro princípios enumerados no art. 37 não esgotam os postulados condicionantes da atividade da Administração Pública.

É significativo que as Constituições estaduais, subordinadas ao paradigma federal, a par de repetir o texto padrão, tenham relacionado outros princípios obrigatórios. Assim a Constituição do Estado de São Paulo aditou referência aos princípios de finalidade, razoabilidade, motivação e interesse público; as de Minas e Sergipe realçam o da razoabilidade, a que a última delas acresce a transparência e a eficiência; a de Alagoas coloca mais os de economicidade, continuidade, planejamento e interesse público; a do Pará realça a participação popular; e a do Amazonas acentua o bem-estar social.

No direito comparado, adquirem ênfase equivalente as Constituições modernas, de que são exemplos as de Espanha, Portugal e Colômbia.

A Constituição espanhola de 1978 assinala, em seu art. 93, a garantia dos princípios da legalidade, hierarquia normativa, publicidade das normas, irretroatividade de disposições sancionatórias não favoráveis ou restritivas de direitos individuais, a segurança jurídica, a responsabilidade e a interdição de arbitrariedade dos poderes públicos.

Esta última garantia - que ingressou no texto constitucional por iniciativa de um eminente administrativista que participava da Assembléia Constituinte, Senador Martin-Retortillo - constitui, na doutrina e jurisprudência espanholas, pedra fundamental do controle da discricionariedade administrativa.

Mais ainda, aprimora a Constituição espanhola a preservação da legalidade quando insere, no art. 173, como deveres da Administração Pública, servir com objetividade aos interesses gerais e atuar de acordo com os princípios da eficácia, hierarquia, descentralização, desconcentração e coordenação plenamente submissos à Lei e ao Direito.

Em linha equivalente, a Constituição portuguesa de 1976 (revista em 1982 e 1989), em seu art. 266, após indicar que a Administração Pública visa à “prossecução do interesse público, no respeito pelos direitos e interesses legalmente protegidos dos cidadãos", determina que, no exercício de suas funções, os órgãos e agentes administrativos devem atuar "com respeito pelos princípios da igualdade, da proporcionalidade, da justiça e da imparcialidade."

Em modelo semelhante, a Constituição da Colômbia de 1991 especifica que a função administrativa, a serviço dos interesses gerais, terá como fundamento os princípios de igualdade, moralidade, eficácia, economia, celeridade, imparcialidade e publicidade (art. 209).

A doutrina e a jurisprudência - e já agora, a própria lei - configuram como desdobramento necessário do conceito de legalidade que a ação administrativa deve 
pautar-se pela observância da finalidade que condiciona a competência da autoridade pública.

Enquanto no ato jurídico privado as razões que inspiram o autor, como o endereço de sua vontade, são em princípio de sua livre escolha, o ato jurídico público, e especialmente o ato administrativo, está vinculado a um fim público específico, ainda que a norma de competência a ele não se refira explicitamente.

Se a autoridade se desvia da finalidade legal própria, $o$ ato administrativo se torna viciado em elemento essencial de legalidade.

Caracteriza-se, na hipótese, o vício que se conceituou como desvio de finalidade ou desvio de poder. A terminologia descreve, graficamente, o movimento ilícito da vontade que, descumprindo o comando imperativo da lei, se dirige a um alvo diverso daquele que lhe é destinado.

A noção do détournement de pouvoir, construída na jurisprudência do Conselho de Estado da França, como vício essencial da legalidade do ato administrativo é, por definição, um limite à ação discricionária, um freio ao transbordamento da competência legal, de modo a impedir que a ação unilateral e compulsória da autoridade possa dedicar-se à consecução de um fim de interesse privado ou mesmo de outro fim público estranho à previsão legal.

Acolhida, amplamente, na generalidade dos sistemas administrativos, a noção de desvio de poder como tipo de ilicitude administrativa, alcançou entre nós, consagração legislativa e jurisprudencial.

Sustentamos, em estudo especial sobre o tema, que a teoria do desvio de poder como vício de legalidade vai além do controle dos atos e contratos administrativos.

Tanto o desvio de poder legislativo, como o desvio de poder jurisdicional se podem caracterizar na medida em que o legislador ou o juiz destoam, de forma manifesta, do âmbito de seus poderes que, embora de reconhecida amplitude, não são ilimitados e atendem a fins que lhe são próprios e definidos ( $R D A$ 188/1).

\section{III}

O diagnóstico de compatibilidade da substância dos atos administrativos, com a finalidade legal a que estão adstritos, conduz a que o exame de sua validade não se contenha nos aspectos exteriores da manifestação de vontade.

O controle de legalidade evoluiu para verificar a existência real dos motivos determinantes da decisão administrativa, a importar no acesso à motivação expressa ou implícita do ato administrativo.

A motivação é, em certos atos, exigência legal de sua validade. Mesmo, porém, quando não exigida, cabe ao intérprete, atento aos antecedentes que condicionam a emissão do ato de vontade do administrador, verificar se os motivos são verdadeiros e aptos a produzir o resultado.

E, mais ainda, o exame da motivação do ato permitirá ao controle de legalidade avaliar se o nexo causal entre os motivos e o resultado do ato administrativo atende a dois outros requisitos essenciais: o da proporcionalidade e o da razoabilidade que são igualmente princípios fundamentais condicionantes do poder administrativo. 
O conceito de legalidade pressupõe, como limite à discricionariedade, que os motivos determinantes sejam razoáveis e o objeto do ato proporcional à finalidade declarada ou implícita na regra de competência.

Conforme a síntese de LUCIA VALE FIGUEIREDO, "traduz o princípio de razoabilidade a relação de congruência lógica entre o fato (o motivo) e a atuação concreta da Administração" (Curso de Direito Administrativo, 2a edição 1985, p. 46).

Acentua CELSO ANTONIO BANDEIRA DE MELLO que o princípio da proporcionalidade deriva do princípio da legalidade na medida em que "a lei outorga competência em vista de certo fim. Toda demasia, todo excesso desnecessário ao seu atendimento, configura uma superação do escopo normativo" (Curso de Direito Administrativo, 5a edição, 1994, p. 28).

Os princípios de que a ação administrativa deve conduzir a um resultado razoável e proporcional à finalidade da lei inibe o abuso de poder e o arbítrio da autoridade liberando ao administrado a lícita fruição de seus direitos e interesses legítimos.

A função administrativa deve, em suma, obedecer ao princípio geral do due process of law, construído pelo direito anglo-saxão, que veio a se incorporar ao texto expresso do direito constitucional brasileiro, como regra tanto processual como de direito material, do devido processo legal (Constituição, art. 5º, n. LIV).

A regra da racionalidade (rationality test) ou o padrão de razoabilidade (reasonableness standard) são, no direito norte-americano, critérios de aferição de legalidade como remédio contra restrições indevidas, de direitos e liberdades na via administrativa e legislativa.

No Reino Unido cabe aos juízes examinar o mérito da ação discricionária na busca da intenção implícita da lei, de modo a afastar o excesso de poder (ultra vires). Conforme o depoimento de WADE, é pela invocação do princípio da razoabilidade que as cortes de justiça têm realizado seus maiores feitos, nos últimos anos (WADE, Administrative Law, 4a edição, p. 10), de que é modelo consagrado a decisão do caso Wednesbury, julgado em 1948. Na França, o Conselho de Estado admite, nas operações de urbanismo e nas expropriações, que se pondere, a noção do custo-benefício, como índice de proporcionalidade entre o sacrifício do direito individual e a utilidade pública do ato, conforme o entendimento firmado na decisão do caso Ville Nouvelle Est, em 28 de maio de 1971.

Especialmente no tocante ao poder de polícia, a jurisprudência francesa valoriza o exame da proporcionalidade dos motivos, que devem ser adequados, sem excessos que ofendam as liberdades públicas ou o direito de propriedade (Traité de Droit Administratif, Laubadère, Venezia e Gaudemet, tomo I, $11^{a ̊ a}$ edição, p. 452; RENÉ CHAPUS, Droit Administratif Général, tomo I, 9a edição, p. 947).

$\mathrm{Na}$ Espanha, a interdição de arbitrariedade, elevada ao plano constitucional, frutificou em extensa elabciação doutrinária e jurisprudencial, especialmente com a presença criativa de GARCIA DE: ENTERRÍA e a recente contribuição de MIGUEL BELTRÁN DE FELIPE.

Em estudo sobre o tema, recentemente divulgado na Revista de Direito Administrativo, volume 204, fizemos o recenseamento da jurisprudência do Supremo Tribunal Federal, que reiteradamente tem acolhido os princípios da razoabilidade $\mathrm{e}$ da proporcionalidade, repelindo a ilegalidade de atos nos quais a discrepância entre o mo- 
tivo e o fim evidencia a falta de congruência ou adequação, tornando excessivo e desarrazoado o objeto da manifestação do legislador ou do administrador, em detrimento de direito ou liberdade.

\section{IV}

Uma palavra final merece ser dita sobre o princípio da impessoalidade que se abriga no enunciado do art. 37 da Constituição e, por via de consequiência, se transmite aos estatutos estaduais.

A atividade da Administração Pública tem como destinatários naturais as pessoas físicas e jurídicas que se subordinam à sua disciplina.

Parecerá, assim, um paradoxo que, embora deva incidir sobre pessoas, a gestão administrativa, terá de ser impessoal, mormente quando a própria Constituição impõe ao Poder Público tratamento peculiar aos integrantes de categorias distintas da coletividade, como a criança o adolescente, o idoso ou o deficiente.

É que, segundo o aforismo grego que Rui Barbosa popularizou, a igualdade consiste em tratar desigualmente os desiguais.

Contudo, a Administração Pública tem como norma básica a proteção de interesses coletivos, ainda que peculiares a grupos definidos em lei e, por esta forma, submetidos a tratamento especial.

O princípio da impessoalidade repele atos discriminatórios que importem favorecimento ou desapreço a membros da sociedade em detrimento da finalidade objetiva da norma de direito a ser aplicada.

Não é indiferente, porém, à Administração Pública a personalidade do administrado. O que se veda é a personificação de seus atos na medida em que abandonem o interesse público para conceder favores ou lesar pessoas ou instituições.

Em síntese, a atividade administrativa pode, em certos casos deve, distinguir entre pessoas, em função de peculiaridades que a lei manda observar. Não poderá jamais discriminar entre elas, sobrepondo o juízo personalista à objetividade legal de tratamento.

O princípio da impessoalidade se aproxima, em suma, do princípio da imparcialidade, um e outro subordinados à regra da neutralidade e isenção administrativas.

Como assinala MARIA SYLVIA ZANELLA DI PIETRO, "a Administração não pode atuar com vistas a prejudicar ou beneficiar pessoas determinadas, uma vez que é sempre o interesse público que tem que nortear o seu comportamento" .

E, em outro sentido, conforme a lição, que invoca, de JOSÉ AFONSO DA SILVA, o autor institucional dos atos é o órgão ou entidade administrativa, e não a pessoa do funcionário, que o representa (Maria Sylvia Zanella di Pietro, Direito Administrativo, 5 a edição, p. 64).

\section{V}

O procedimento administrativo deve atender, em sua funcionalidade, a princípios fundamentais que, como visto, presidem à legalidade da Administração Pública. 
Em recente projeto de lei, elaborado a pedido do Governo por comissão de ilustres professores, que me coube presidir - cujo texto está sendo posto à disposição dos participantes deste Congresso, foram consagradas as normas gerais que devem comandar o processo administrativo federal.

Como sintetizado na Exposição de Motivos, o anteprojeto procurou enunciar os critérios básicos a que se devem submeter os processos administrativos.

Atento ao comando do art. 37 da Constituição, destacou a aplicação dos princípios essenciais de legalidade, impessoalidade, moralidade e publicidade. A eles foram, porém, acrescidos, outros igualmente estruturais, acolhidos em lei, como na doutrina e na jurisprudência.

Entendeu-se que a conduta da Administração deve pautar-se necessariamente pela finalidade da competência e conduzir sua atuação pelos postulados correlatos de proporcionalidade e razoabilidade. $O$ diagnóstico da presença de tais elementos repousa na motivação dos atos administrativos, moldados pelo interesse público e visando à segurança jurídica na prestação dos serviços públicos.

Os debates que se sucedam contribuirão certamente para o aperfeiçoamento da iniciativa. 